\title{
Microstructural characterization of metal matrix composites by analytical electron microscopy
}

\author{
Regine Molins $\left({ }^{1}\right)$, Yolande $\operatorname{Kihn}\left({ }^{2}\right)$, Jean Sévely $\left({ }^{2}\right)$, Gilbert Thollet $\left({ }^{3}\right)$ \\ and Claude Esnouf $\left({ }^{3}\right)$ \\ ( $\left.{ }^{1}\right)$ Ecole des Mines de Paris, Centre des Matériaux, BP.87, 91003 Evry, France \\ (2) CEMES-LOE BP. 4347, 31055 Toulouse Cedex, France \\ (3) GEMPPM-URA 341, Bat. 502, INSA, 69621 Villeurbanne Cedex, France
}

(Received December 21, 1990; accepted February 01, 1991)

\begin{abstract}
Résumé. - Certaines propriétés mécaniques des matériaux Composites à Matrices Métalliques (CMM) sont améliorées par rapport à celles des alliages de base conventionnels, notamment la rigidité, la résistance, la dureté et la stabilité en température. Ces propriétés sont en relation directe avec la composition chimique de la matrice et des renforts, avec leur microstructure mais aussi avec le mode d'élaboration du composite. L'état des zones réactionnelles entre les différentes phases dans ces matériaux, en particulier des interfaces matrice / renforts, conditionne la rigidité et la résistance à la rupture. Le but de cette communication est de souligner les possibilités de différentes techniques d'analyse en microscopie électronique (imagerie, EDS, EELS, diffraction en faisceau convergent) pour la caractérisation de ségrégation de magnésium dans le cas de renforts oxydés et non-oxydés. Ceci permet d'identifier le spinelle $\mathrm{MgAl}_{2} \mathrm{O}_{4}$ à l'interface alumine / matrice à base d'aluminium, et de comprendre les différentes réactions chimiques mises en jeu lors de l'élaboration du matériau.
\end{abstract}

\footnotetext{
Abstract. - Metal Matrix Composites have several advantages over the matrix alloys, such as higher stiffness and strength, but they suffer from lower fracture toughness. This is, of course, dependent on the chemical composition of the matrix and of the reinforcement and also on the microstructure and on the processing techniques. The reactions between the different phases in the materials, in particular the matrix / reinforcement interfaces condition strength and toughness. The purpose of the present paper is to outline the potential of different analytical electron microscopy techniques (direct imaging, EDS, EELS, convergent beam diffraction) for the characterization of magnesium segregation in the case of oxide and non-oxide reinforcements. This allows to identify $\mathrm{MgAl}_{2} \mathrm{O}_{4}$ spinel at the interface between alumina and an aluminium base matrix, and to understand the different chemical reactions which are involved in the processing.
} 


\section{Introduction.}

Metallic alloys, when reinforced with long or short fibres, whiskers or particles, offer potentials for significant improvements in mechanical performance in comparison with conventional alloys. This class of materials is called "Metal Matrix Composites" (MMC) and has been under development for more than 20 years. The first applications have concerned the aerospace domain and are now followed by applications in other industries.

Table I compares typical mechanical properties in the two types of materials (reinforced and unreinforced).

Table I. - Mechanical properties of an aluminium based composite compared with those of the monolithic alloy [1].

\begin{tabular}{|l|c|c|c|c|}
\hline & $\begin{array}{c}\text { Yield stress } \\
(\mathrm{MPa})\end{array}$ & $\begin{array}{c}\text { Modulus } \\
(\mathrm{GPa})\end{array}$ & $\begin{array}{c}\text { Ultimate stress } \\
(\mathrm{MPa})\end{array}$ & $\begin{array}{c}\text { Elongation } \\
(\%)\end{array}$ \\
\hline $6061-\beta-\mathrm{SiC}_{\text {whiskers }}(17 \%)$ & 421 & 110 & 529 & 4.8 \\
\hline 6061 non reinforced & 274 & 70 & 309 & 16 \\
\hline
\end{tabular}

The properties of MMC are determined by a complex interplay between, the interface behaviour and the microstructural characteristics of materials. The ability to transfer the applied loads from the matrix to the fibres depends on the bonding interface between them. In consequence, the matrix composition has to be selected on the basis of its interaction with the reinforcement.

Metal Matrix Composites have several advantages over the matrix alloys, such as higher stiffness and strength, but they suffer from lower fracture toughness. Many different mechanisms have been discussed in order to explain the MMC behaviours; they include the matrix and interfacial precipitations, the enhanced dislocation density associated with residual stresses generated during cooling from the processing temperature as a result of the thermal expansion mismatch between the components of the composite.

These mechanisms are often operated as a consequence of the processing techniques. They have been recently reviewed $[2,3]$ in the case of discontinuous type reinforcement (DMMC). DMMCs concerned metal matrix reinforced with whiskers, short fibres (chopped or milled) or ceramic particles. The other MMC type is a composite with continuous filaments. Briefly, three ways are used to manufacture DMMCs:

first, the molten metal processing which offers the widest range of variations. One of them is the standard squeeze casting method: molten metal is squeezed into a preform composed of an agglomeration of short fibres using a hydraulic press;

secondly, the powder processing (PM) involving densification and shaping of mixtures of the matrix alloy and the reinforcing phase into a powder and then to consolidate them after mixing.

thirdly, the spray deposition processing which is a recent process: both matrix and reinforcement are projected with an inert carrier gas into a plasma jet inside a low-pressure chamber.

Indeed the processing choice may be important for the possible interfacial reaction or segregation between fibres and matrix especially in the case of molten metal processing [4-8]. This results in a variation of the alloy concentration in the matrix and then degrades the age-hardening characteristics of composites [9-13]. In many pratical cases, the composition of the matrix of MMC 
is the same as the one used for unreinforced aluminium based alloys. Classical solute elements of these alloys are copper, magnesium, silicon, iron... Thermodynamic considerations on the free energy for possible reactions between these elements and the reinforcements can be invoked. In particular, magnesium is often considered when oxide reinforcement are used.

The purpose of the present paper is to outline some results obtained by transmission electron microscopy (TEM) on the microstructures of several composites as a function of their processing. Changes of the microstructure of materials containing oxide and non-oxide reinforcements have been analysed using different high resolution techniques for direct observations and chemical analyses.

\section{Experimental procedures.}

2.1 ELECTRON MICROSCOPY AND MICROANALYSIS TECHNIQUES. - Our studies were performed using various electron microscopes : Philips EM430, Philips EM400 and JEOL 200CX, equipped with X-ray spectrometer and electron energy loss spectrometer (EELS) used in the sequential mode, and a $1 \mathrm{MV}$ microscope quipped with an $\Omega$ filter [14]. TEM X-ray analyses (EDS) have been performed with a minimum probe size varying from 5 to $20 \mathrm{~nm}$, depending on the microscope. For EELS analyses concerning the detection of light elements such as oxygen and magnesium, the probe size ranged from 15 to $100 \mathrm{~nm}$.

After a mechanical grinding to a thickness of $100 \mu \mathrm{m}$, the samples were dimpled to $20 \mu \mathrm{m}$. They were then ion thinned at $5 \mathrm{keV}$, with argon ions, at a $15^{\circ}$ incidence angle, until a hole was laser detected at the center. During all the thinning, the foil was cooled by liquid nitrogen in order to avoid irradiation damage of the aluminium alloy. We finished the thinning at $10^{\circ}$ incidence for a few hours to enhance thin areas in the specimen.

2.2 MATERIALS. - We have examined various metal matrix composites which differ by the matrix composition, the reinforcement structure and the processing.

2.2.1 Fibre nature. - The fibres are SiC whiskers, short alumina fibres and short mullite fibres.

SiC whiskers from ARCO. Their diameter varies from 0.3 to $1 \mu \mathrm{m}$ and their length from 3 to $50 \mu \mathrm{m}$.

TEM cross section observations show a non uniform distribution of the fibres. The whiskers have a $\beta$-SiC cubic structure. They are oriented near the $\langle 111\rangle$ zone axis, the side faces being oriented $\{112\}$.

At the core of the fibres, we noted inclusions (Fig. 1a), the diameter of the largest ones not exceeding $10 \mathrm{~nm}$. X-ray analyses indicate that these inclusions are composed of aluminium, calcium, manganese, iron and magnesium (Fig. 1c). Electron diffraction pattern oriented along $\langle 111\rangle_{\beta}$ shows that these inclusions have an orientation relationship with the SiC phase (Fig. 1b).

Longitudinal observation shows evidence of many stacking faults in the (111) planes perpendicular to the growing axis. These faults modify the crystalline planes sequence, introducing hexagonal slices inside the cubic structure. The $\{112\}$ side faces are rough because of small facets on $\{111\}$ planes due to the presence of inclusions at the core of the whiskers [15] (Fig. 2).

$\delta$ alumina fibres: are mainly short fibres. Their diameter varies from 5 to $25 \mu \mathrm{m}$ and their length is lower than $50 \mu \mathrm{m}$. An addition of $5 \mathrm{wt} \%$ of silica allows to stabilize the $\delta$ crystalline structure of $\mathrm{Al}_{2} \mathrm{O}_{3}$ fibres. But X-ray diffraction studies of $\delta$ alumina fibre preforms indicate the presence of small amounts of $\gamma$ and $\alpha$ alumina. TEM cross section observation gives evidence of a monocrystalline sleeve on some fibres (Fig. 3a). It can be observed on the longitudinal view of figure $3 b(\mathrm{~A})$. Electron diffraction pattern allows us to identify it as pure $\gamma$ alumina. The axial 


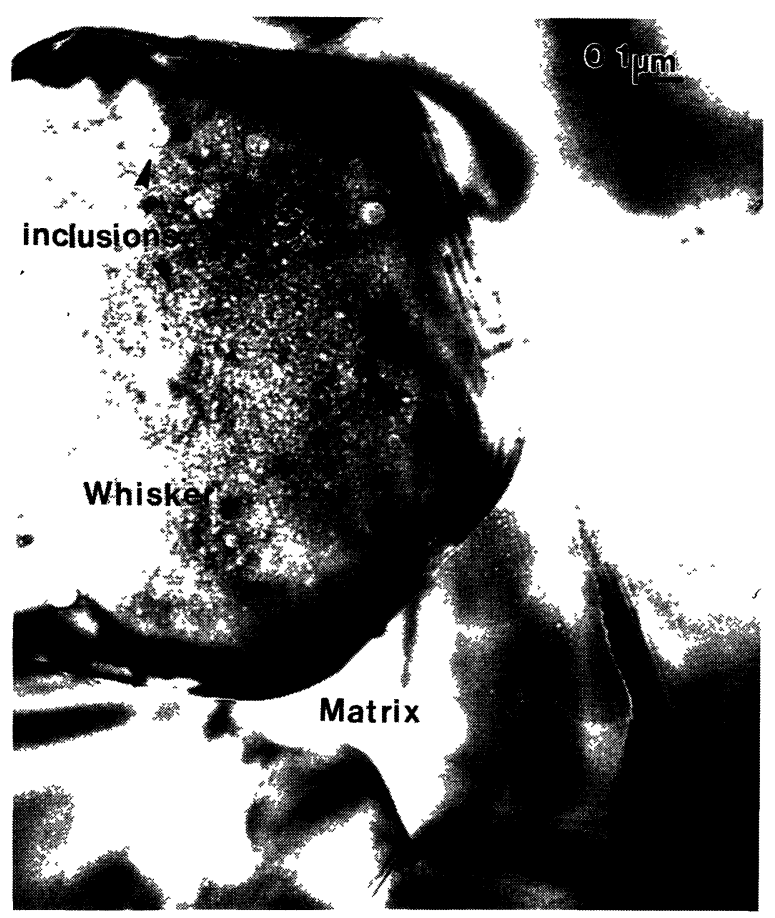

a)

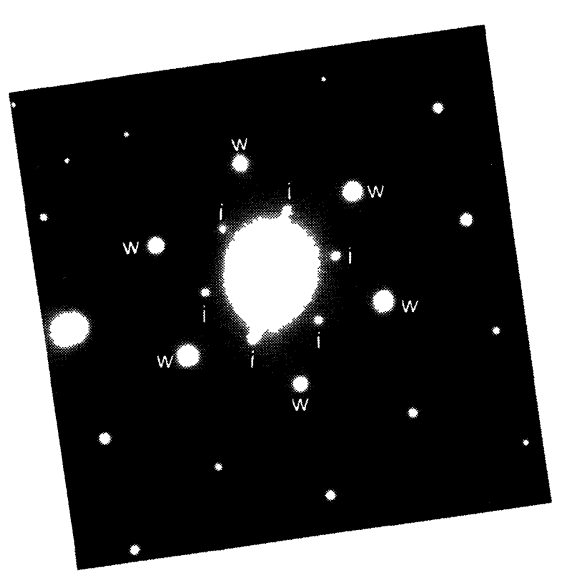

b)

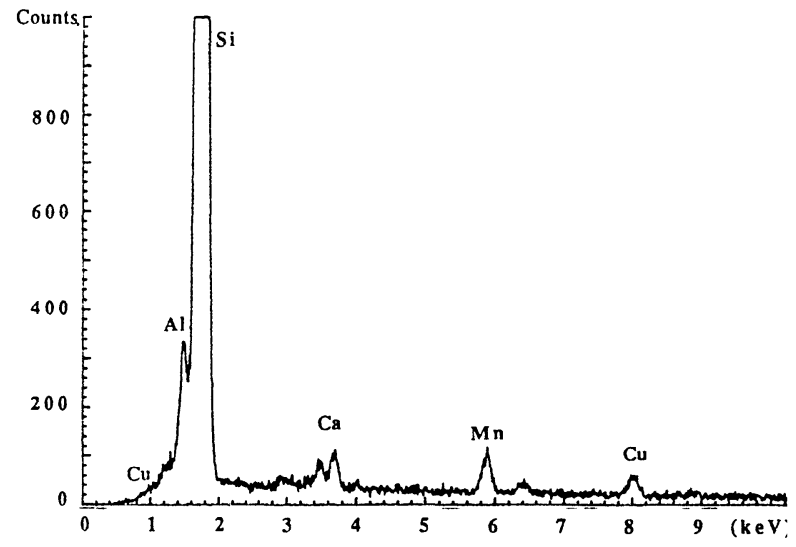

C)

Fig. 1. - a) cross section image of $\mathrm{SiC}$ whikers with microcrystalline inclusions in the core region showed by arrows. b) $\langle 111\rangle_{\beta}$ orientation of the $\mathrm{SiC}$ whiskers (w) with additional spots from inclusions (i). probe size $300 \mathrm{~nm}$. c) X-ray analysis of the core region of the whiskers. 

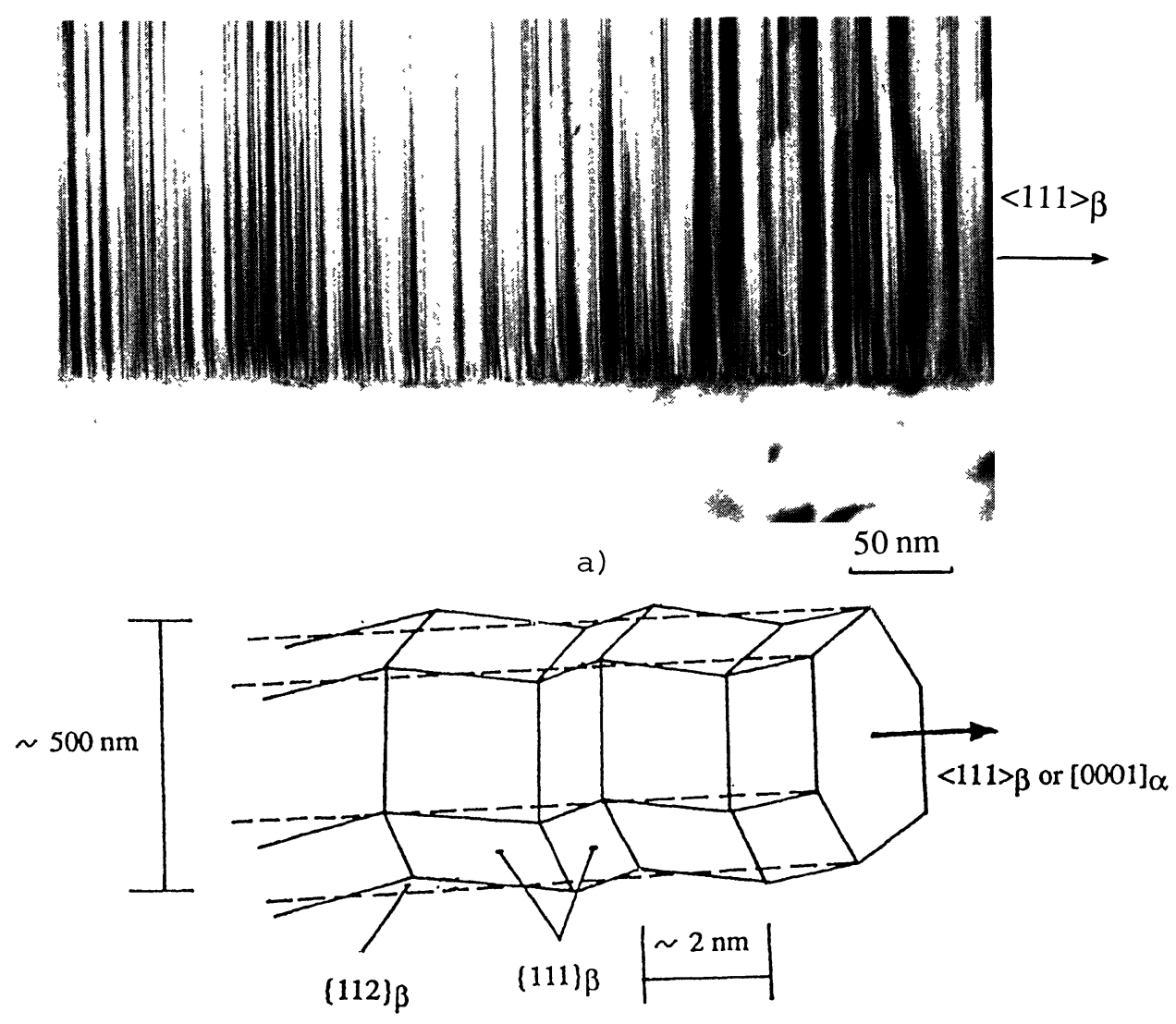

b)

Fig. 2. - a) Longitudinal view of a $\mathrm{SiC}$ whisker showing the roughness of the $\{112\}_{\beta}$ side face. b) Diagram between different crystalline sequences of the side face facetting.

part of the fibre (B) is composed of small grains of alumina, less than $50 \mathrm{~nm}$ in diameter, with amorphous silica segregated at the grain boundaries, inhibiting the coarsening of the grains.

Figure 4 shows microcrystallites on the side of the alumina fibre, allowing a good mechanical bonding between the ceramic and the matrix.

Mullite: short fibres of mullite have an average diameter of $10 \mu \mathrm{m}$ (Fig. 5a) with a mean grain size about $0.2 \mu \mathrm{m}$.

The nominal composition of mullite is $3 \mathrm{Al}_{2} \mathrm{O}_{3} .2 \mathrm{SiO}_{2}$. It corresponds to a narrow stable solid solution in the alumina-silica system. But different heat treatments of mullite can produce metastable equilibria. The mullite composition is achieved by substitution of $\mathrm{Si}^{4+}$ ions by $\mathrm{Al}^{3+}$ ions in tetrahedral chains of alternating $\mathrm{Al}$ and $\mathrm{Si}$ sequence. This is accompanied by a statistical removal of oxygen atoms within the orthorhombic unit cell. The oxygen vacancies arrange themselves into ordered domains producing superlattice points in the reciprocal cell. Indeed the solid solution of mullite may be expressed by the formula $\mathrm{Al}_{2}\left\{\mathrm{Al}_{2+2 x} \mathrm{Si}_{2-2 x}\right\} O_{10-x}$ where $x$ designates the number of oxygen atoms missing per unit cell. So, the ratio $\mathrm{Al}_{2} \mathrm{O}_{3} / \mathrm{SiO}_{2}$ is given by:

$$
\mathrm{Al}_{2} \mathrm{O}_{3} / \mathrm{SiO}_{2}=(1+x / 2) /(1-x)
$$




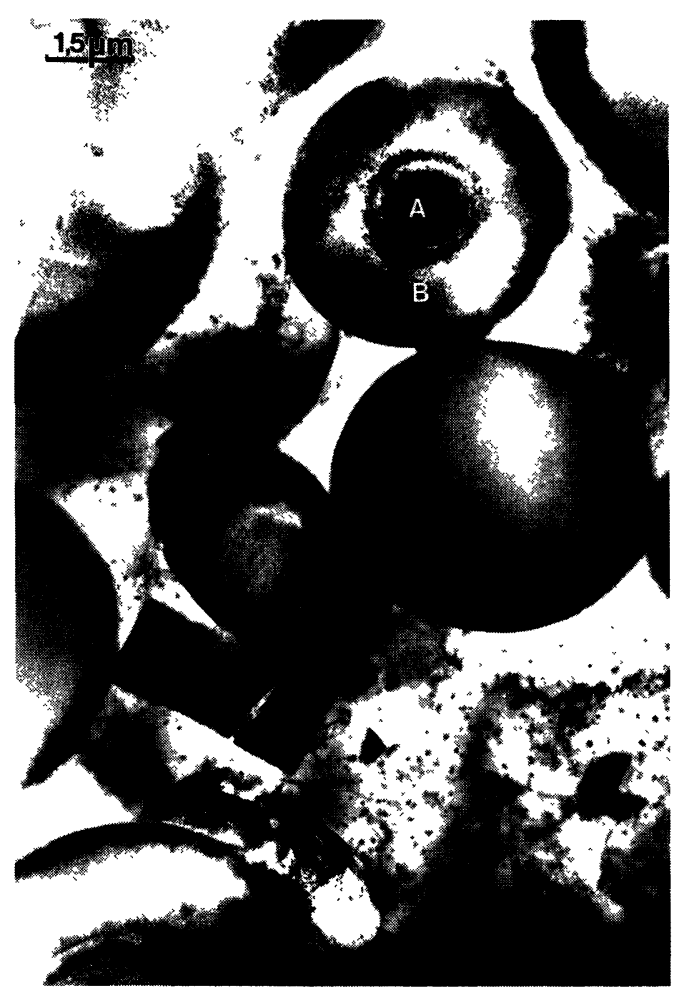

a)

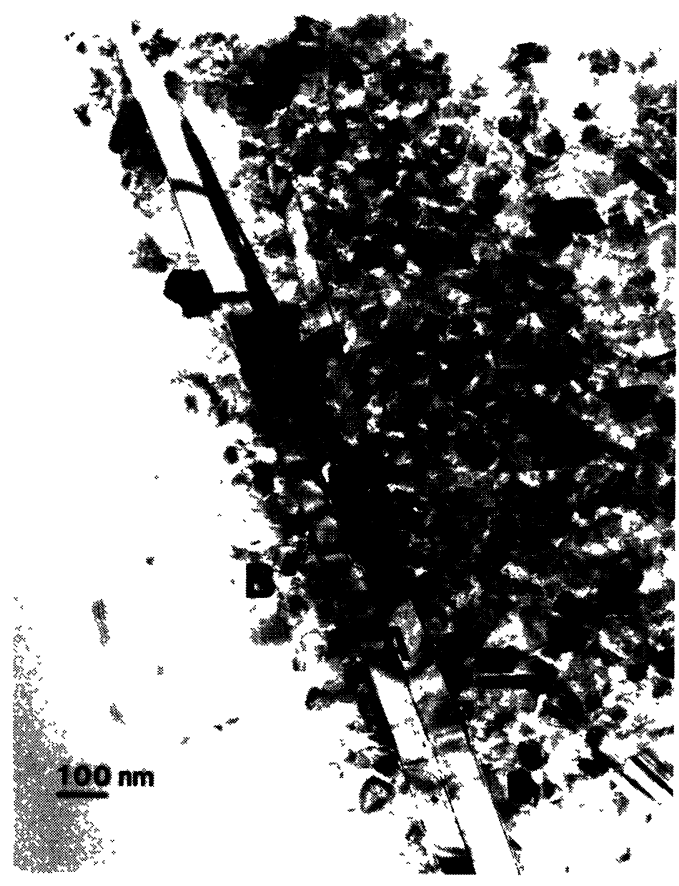

b)

Fig. 3. - a) Transverse section of $\delta$ alumina fibres / 6061 alloy composite. b) Longitudinal section of a $\delta$ alumina fibre. A) monocrystalline part corresponding to pure alumina. B) polycrystalline part: alumina grains with a silica binder.

The chemical composition domain is starting from silica rich mullite $(x=0.17)$ to alumina mullite $(x=0.59)$. Beyond this value the mullite solide solution is degenerated into tetragonal iota-alumina [16].

When increasing alumina content, the development of superstructure reflections is observed in the diffraction pattern and a $2 s$ vector may be defined as joining the satellite reflections in the $\{$ h01\} net (see satellites noted "e" in Fig. 5b). Cameron [16] showed that the magnitude of the $s$ vector is related with the $x$ value.

The average value of the experimental ratio $\mathrm{Al} / \mathrm{Si}$ measured by EDS with a probe size covering several grains in the fibres is about 3 , from which a $x$ value equal to $0.25\left(60\right.$ mole $\left.\% \mathrm{Al}_{2} \mathrm{O}_{3}\right)$ can be deduced. Such a value corresponds to the practical 3:2 mullite.

A more local analysis, at the grain size probe, $\sim 0.2 \mu \mathrm{m}$ in diameter, either by diffraction or by EDS allows to observe heterogeneities in the composition. This is illustrated in figure 5 where the composition of the fibre corresponds to an aluminous mullite with $x=0.57$ i.e. 75 mole\% $\mathrm{Al}_{2} \mathrm{O}_{3}$. Moreover a streaking effect appears on satellite spots, which is coherent with the previous value, according to a diffraction work [16]. This streaking can be explained by a finely twinned structure of mullite [17]. 


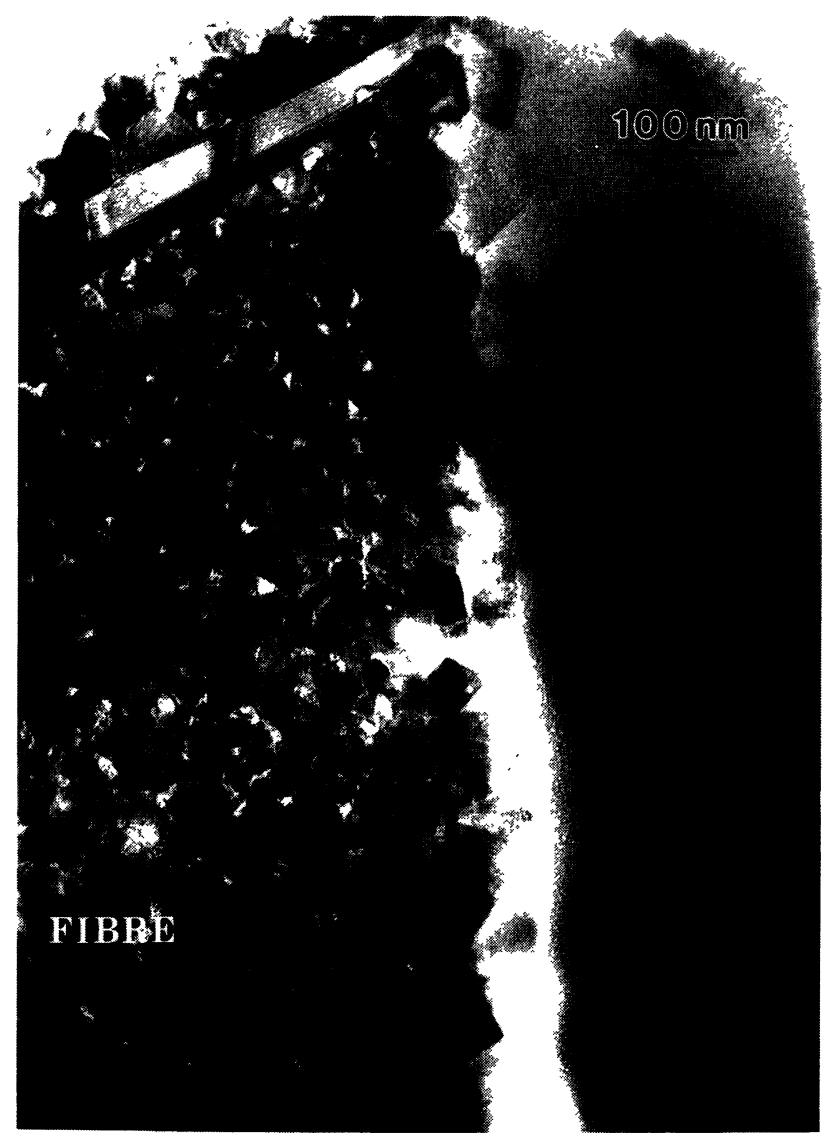

Fig. 4. - Edge on view of the interface in a $\delta$ alumina fibre / 6061 alloy composite.

2.2.2 Matrix composition. - All the investigated materials have an aluminium alloy matrix. We considered two types of matrix :

2024 alloy : nominally containing $4.5 \mathrm{wt} \% \mathrm{Cu}, 1.5 \mathrm{wt} \% \mathrm{Mg}, 0.5 \mathrm{wt} \% \mathrm{Si}$ and $0.6 \mathrm{wt} \% \mathrm{Mn}$.

6061 alloy : nominally containing $0.25 \mathrm{wt} \% \mathrm{Cu}, 1 \mathrm{wt} \% \mathrm{Mg}, 0.6 \mathrm{wt} \% \mathrm{Si}, 0.3 \mathrm{wt} \% \mathrm{Fe}, 0.1 \mathrm{wt} \% \mathrm{Mn}$ and $0.25 \mathrm{wt} \% \mathrm{Cr}$.

The grain size in the matrix depends on the volume fraction of the fibres and on their repartition; it increases when the fibres are dispersed; its average value is generally $1 \mu \mathrm{m}$ for composites reinforced with $\mathrm{SiC}$ whiskers, and a few $\mu \mathrm{m}$ for the other composites reinforced with $\delta$ alumina or mullite fibres.

All the preforms have been heat treated at $1073 \mathrm{~K}$ during 30 minutes to 1 hour.

After infiltration, the materials have been heat treated:

- a T6 treatment for the 6061 matrix: 4 hours at $808 \mathrm{~K}$, water quenched, followed by an aging treatment of 8 hours at $448 \mathrm{~K}$.

- a T4 treatment for the 2024 matrix: 4 hours at $765 \mathrm{~K}$, water quenched.

Through these treatments, aluminium alloys are structurally hardened through $\mathrm{G} P$ zones and $\beta^{\prime \prime}\left(\mathrm{Mg}_{2} \mathrm{Si}\right)$ for 6061 alloy or $\mathrm{G} \mathrm{P}$ zones for 2024 alloy precipitation. The matrix also contains numerous spherical inclusions, about $0.1 \mu \mathrm{m}$ in diameter, dispersed in the grains. $\mathrm{X}$-ray analysis 


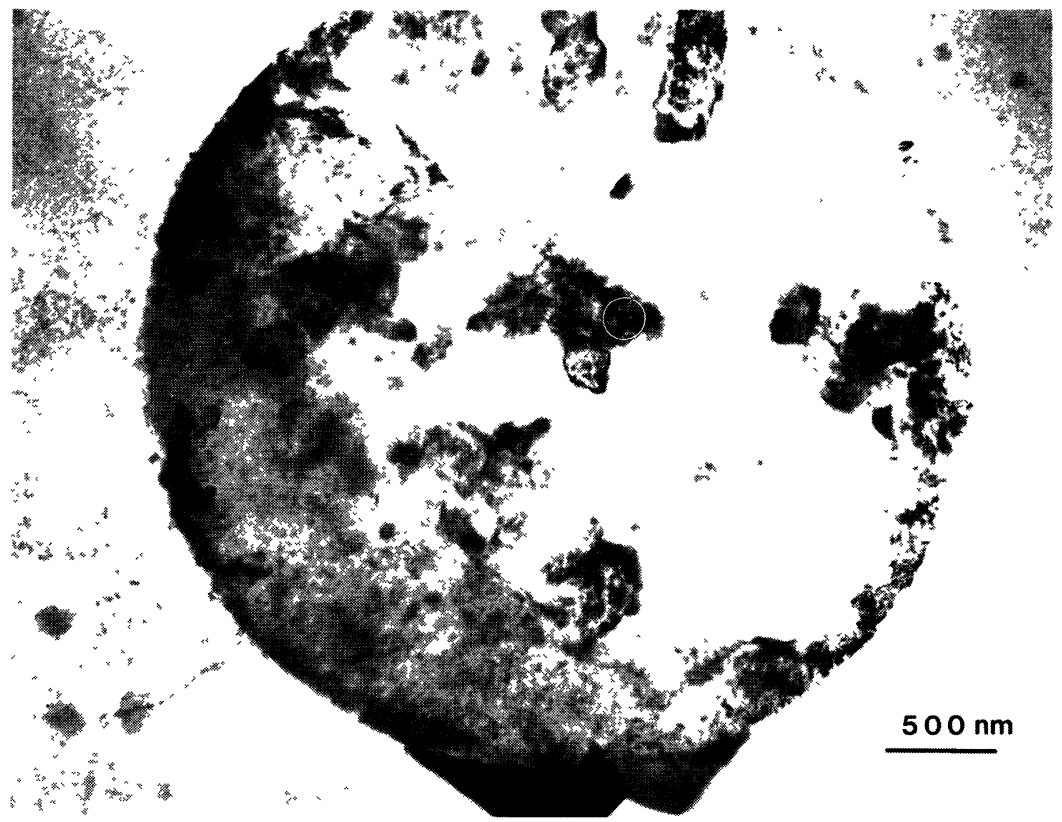

a)

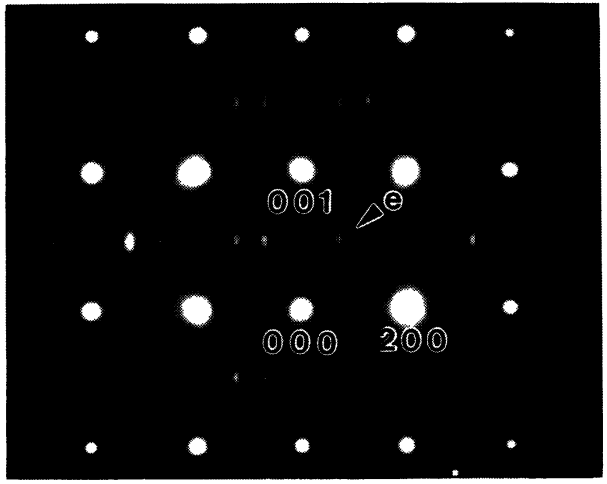

b)

Fig. 5. - a) Cross section view of a mullite fibre. b) Typical diffraction pattern got with any part of the mullite fibre (zone axis [010]). The presence of satellites designated by " $\mathrm{e}$ " is the consequence of an incommensurate structure due to oxygen vacancies (probe size $200 \mathrm{~nm}$ ).

indicates that these precipitates are intermetallics containing silicon, copper, manganese and iron.

For the composites reinforced with short $\delta$ alumina or mullite fibres, we have increased the annealing time at $808 \mathrm{~K}: 50 \mathrm{~h}$ for mullite and $120 \mathrm{~h}$ for $\delta$ alumina, to promote further interface reactions and easier identification of the precipitates which are formed along the interface. 
Table II gives the main features of the materials examined in this study.

Table II.

\begin{tabular}{|c|c|c|c|c|}
\hline $\begin{array}{c}\text { Matrix } \\
\text { type }\end{array}$ & $\begin{array}{c}\text { Fibres } \\
\text { natures }\end{array}$ & $\begin{array}{c}\text { Fibres } \\
\text { volume fraction }\end{array}$ & $\begin{array}{c}\text { Heat } \\
\text { treatment }\end{array}$ & Processing \\
\hline 2024 & $\mathrm{SiC}$ whiskers & $25 \%$ & $\mathrm{~T} 4$ & $\mathrm{P} \mathrm{M}$ \\
\hline 2024 & $\mathrm{SiC}$ whiskers & $15 \%$ & $\mathrm{~T} 4$ & Squeeze casting \\
\hline 6061 & $\delta$ alumina & $15 \%$ & $\mathrm{~T} 6$ & Squeeze casting \\
\hline 6061 & mullite & $15 \%$ & $\mathrm{~T} 6$ & Squeeze casting \\
\hline
\end{tabular}

\section{Results.}

3.1 AS ELABORATED COMPOSITE. - Observations of MMC without heat treatment after processing, have revealed the presence of numerous intermetallic particles on the fibres. They are situated at the intersection of the grain boundaries and of the fibres and have a sharp-peak shape as shown in the figure 6a in the case of $\delta$ alumina fibre / 2024 matrix. They contain the alloying elements such as magnesium, silicon, copper. They can be explained by the displacement of solidification fronts initiated from different germs near the reinforcement surface as shown in the figure $6 \mathrm{~b}$.

\subsection{HEAT TREATED COMPOSITE.}

3.2.1 SiC whiskers / 2024 alloy. - For the composites elaborated by squeeze casting, an elemental concentration linescan (with X-rays) through the interface with a $5 \mathrm{~nm}$ probe size gives evidence of a few percent enrichment of $\mathrm{Mg}$ at the fibre-matrix interface. (Fig. 7a).

This result can be confirmed by EELS measurements by comparing different spectra from different part of the material: inside the fibres, at the interface and in the matrix (Fig. 7b1) respectively. In spite of the signal / noise ratio in this part of the spectra, a distribution corresponding to the magnesium $\mathrm{K}$ edge is systematically observed only at the interface in agreement with EDS measurements. It was not possible to determine the chemical composition of the interfacial precipitates due to the probe size $(20 \mathrm{~nm})$ compared to the width of the interface.

In the composite elaborated by powder metallurgy, magnesium is not detected at the interface (Fig. 7b2).

For both processings, EELS analysis does not shown any evidence of a magnesium content inside the fibre, even near the interface and the quantitative analysis is coherent with a SiC composition of the fibre. These observations show that magnesium segregations are produced outside the fibres.

3.2.2 $\delta$ alumina fibres / 6061 alloy. - Cross section and longitudinal observations show a good bonding with no reaction zone at the interface. EDS analysis through the interface reveals a diffusion of magnesium from the matrix to the fibres (Fig. 8a).

A microprobe investigation has been performed for a fibre crossing in order to confirm this result (Fig. 8b). The average magnesium content observed in a fibre of $25 \mu \mathrm{m}$ is about $3 \mathrm{wt} \%$ whereas the magnesium content in the matrix is less than $0.1 w t \%$, a tenth of the nominal content. No magnesium can be detected on the as received $\delta$ alumina fibres (Tab. III). 


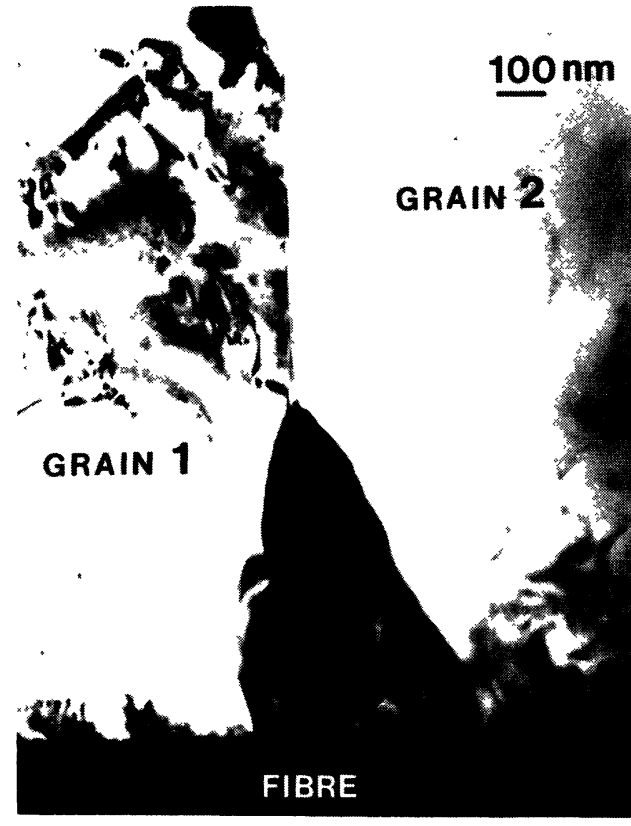

a)

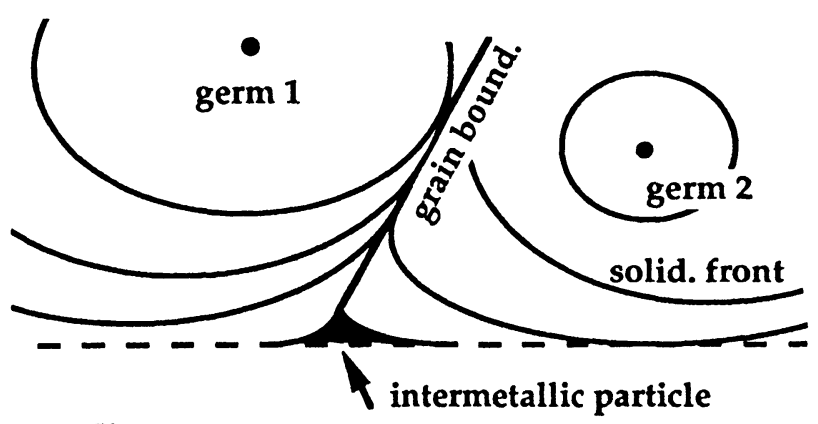

Fibre

Fig. 6. - a) Interfacial segregation in the as elaborated $\delta$ alumina fibre / 2024 composite. b) Schematic sequence of solidification front initiated from two germs out of the reinforcement surface. Formation of a particle at the fibre / matrix interface and along grain boundary.

In this composite, all the magnesium appears to have diffused from the matrix to the fibres (Fig. $8 \mathrm{~b}$ ). Thus no residual magnesium remains in the matrix to precipitate $\mathrm{Mg}_{2} \mathrm{Si}$, which is considered as the structural hardening mechanism of the material.

This is confirmed by the associated diffraction pattern where no streak characteristic of $\mathrm{Mg}_{2} \mathrm{Si}$ precipitation in the matrix along the $\langle 100\rangle$ directions on a $\langle 001\rangle$ zone axis was observed $[11,18]$.

In order to enhance the degradation of the fibres by the alloying elements of the matrix, we have studied the case of MMC 6061 matrix / $\delta$ alumina fibres heated at $808 \mathrm{~K}$ for 120 hours. A very deep modification of the fibre microstructure is observed (Fig. 9a). The part corresponding to small grains of $\delta$-alumina is changed in a finely dispersed structure (Fig. $9 \mathrm{~b}$ ). The location of tubular monocrystalline domains remains visible, but spots in the diffraction pattern (Fig. 9d) corresponding to this region indicates that magnesium oxide replaces alumina. The diffraction 
rings appearing on the pattern correspond to the finely dispersed regions and are attributed to the spinel phase $\mathrm{MgAl}_{2} \mathrm{O}_{4}$. Table III gives the local composition inside the degraded fibre. The initial composition of the matrix and the fibre are given for comparison. A high silicon content is observed in the particles attached to the fibres (Fig. 9c). They also contain some other alloying elements.

Table III. - Metallic species composition inside $\delta$ alumina fibres (MMC $\delta$ alumina / 6061, 120 hat $808 \mathrm{~K})$.

\begin{tabular}{|c|c|c|c|c|c|c|}
\hline $\begin{array}{c}\text { Numbers of } \\
\text { analysis }\end{array}$ & $\begin{array}{c}\mathrm{Al} \\
\text { at\% }\end{array}$ & $\mathrm{Mg}$ & $\mathrm{Si}$ & $\mathrm{Fe}$ & $\mathrm{Cr}$ & $\mathrm{Mn}$ \\
\hline 1 & 99.2 & $\sim 0$ & 0.8 & - & - & - \\
2 & 94.3 & 4.2 & 1.5 & - & - & - \\
3 & 95.2 & 3.1 & 1.7 & - & - & - \\
4 & 84.9 & 13.1 & 2.0 & - & - & - \\
5 & 73.4 & $\sim 0$ & 12.1 & 6.0 & 4.9 & 3.6 \\
\hline 6061 & 97.5 & 1.0 & 0.6 & 0.3 & 0.25 & 0.1 \\
\hline$\delta$ alumina & 95.4 & - & 4.6 & - & - & - \\
\hline
\end{tabular}

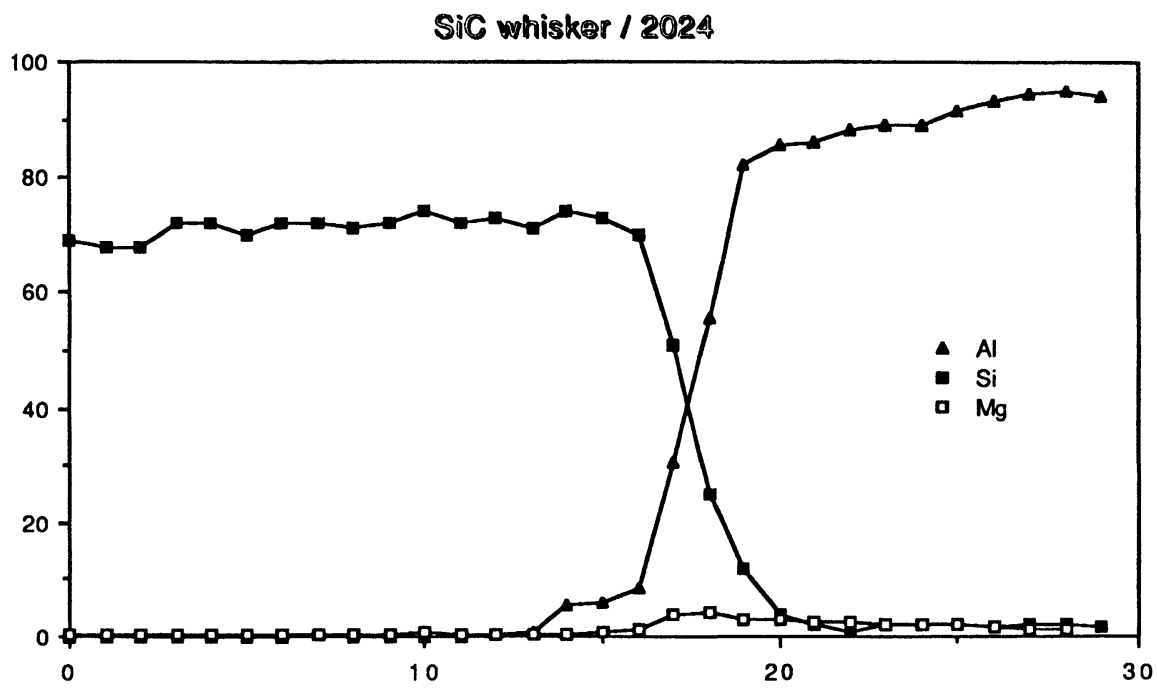

a)

Fig. 7. - a) Elemental concentration linescan through the $\mathrm{SiC} / 2024$ alloy interface for the squeeze cast composite. b) EELS analyses, 1) composite elaborated by squeeze casting. 2) composite elaborated by powder metallurgy. 

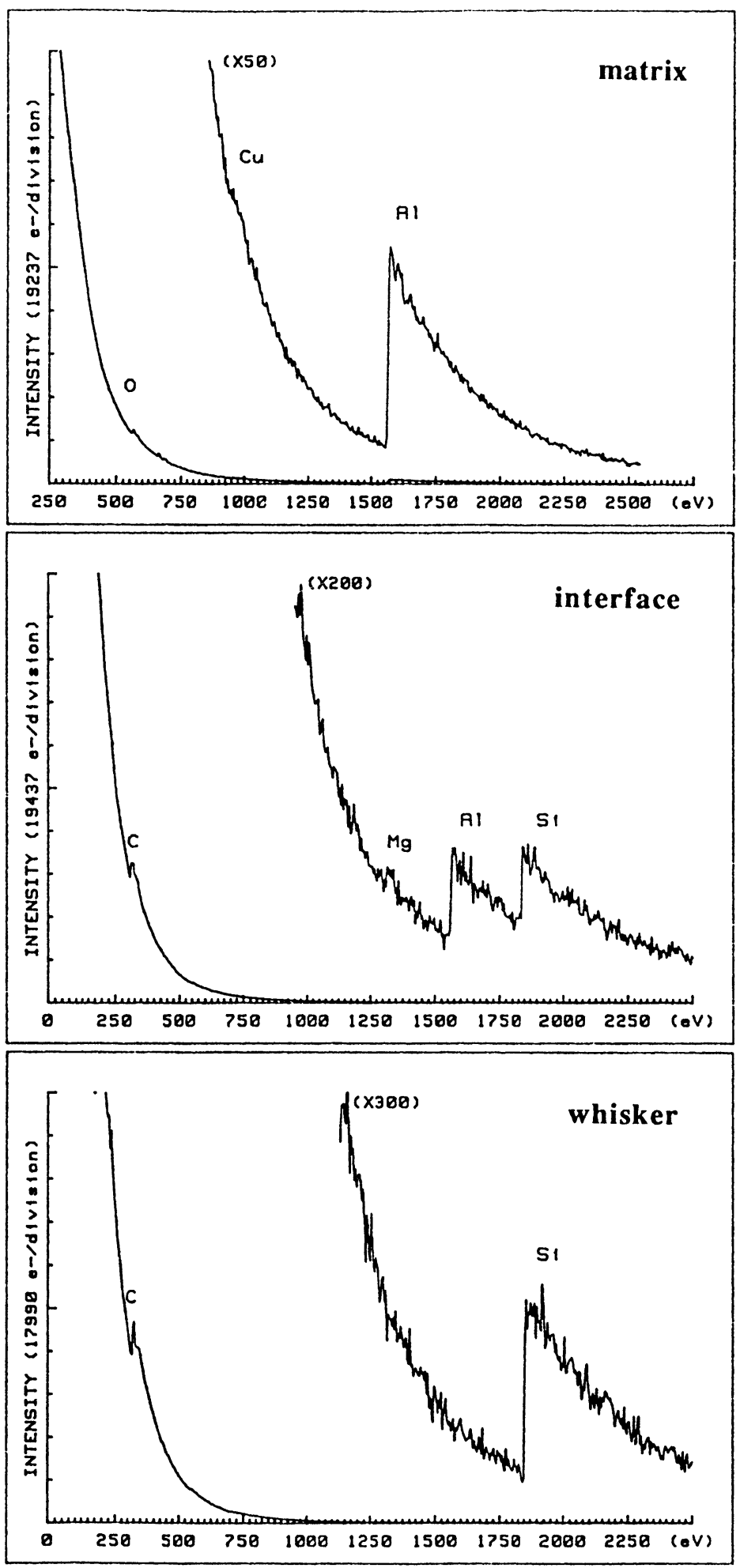

Fig. $7 \mathrm{~b} 1$. 


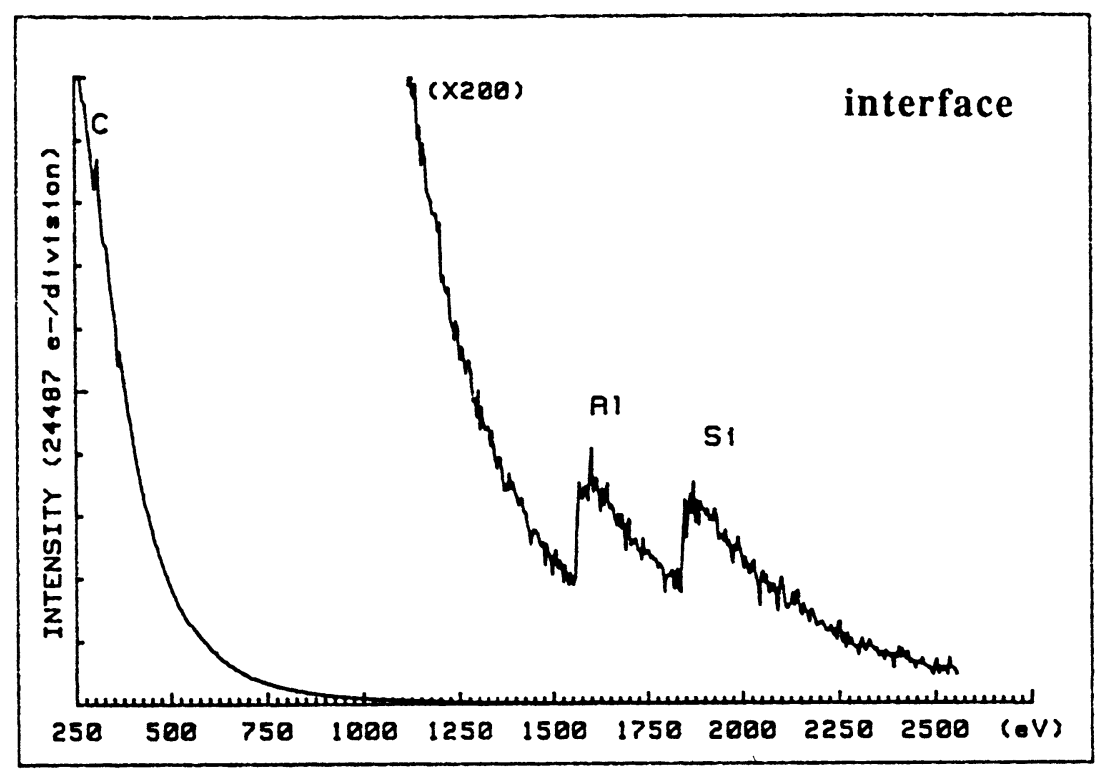

Fig. $7 \mathrm{~b} 2$.

The results are obtained using "SQMTF" (Semi Quantitative Metallurgical Thin Foils) program where absorption correction is included.

The points of measurements are shown in figure 9.

3.2.3 Mullite fibres / 6061 alloy. - The material has been first investigated after a typical T6 treatment. STEM X-ray analyses show a slight increase of magnesium at the interface. After an annealing treatment of $50 \mathrm{~h}$ at $808 \mathrm{~K}$, the magnesium content further increases at the interface.

An EDS linescan, $1 \mu \mathrm{m}$ wide through the interface, reveals a magnesium content increase on $0.2 \mu \mathrm{m}$ with a diffusion inside the fibre (Fig. 10b), but magnesium does not penetrate to the fibre core.

The size of the crystals in the reaction zone after 50 hours (Fig. 10a), is sufficient to determine their composition by EELS quantification [26] as $\mathrm{MgAl}_{2} \mathrm{O}_{4}$ (Fig. 10d). That is in good agreement with the identification deduced from microdiffraction patterns (Fig. 10a).

$\mathrm{X}$-ray maps (spot size $5 \mathrm{~nm}$ ) showing magnesium, aluminium and silicon repartition confirm this magnesium enrichment along the interfaces, on a distance varying from 0.1 to $0.2 \mu \mathrm{m}$. (Fig. 10c).

\section{Discussion and conclusion.}

The liquid metal processing of MMC involves significant segregations during the solidification of the matrix $[19,20]$. Alloying elements in the melt are swept on the solidification front. At the end of the solidification, the alloy-enriched residual liquid originates intermetallic particles. As a result, these coarse, brittle particles reduce ductility and toughness; they also change the interface behaviour if the final solidification takes place at the fibre / matrix interface.

As shown in figure 6a, intermetallic particles are present at the intersection of grain boundaries with the reinforcement / matrix interface. Such a result can be explained by a nucleation of solid germs out of the reinforcement surfaces (Fig. 6b). The surface tension on the solidification front is responsible for the confining of alloying elements in the form of peak-shape segregation. 


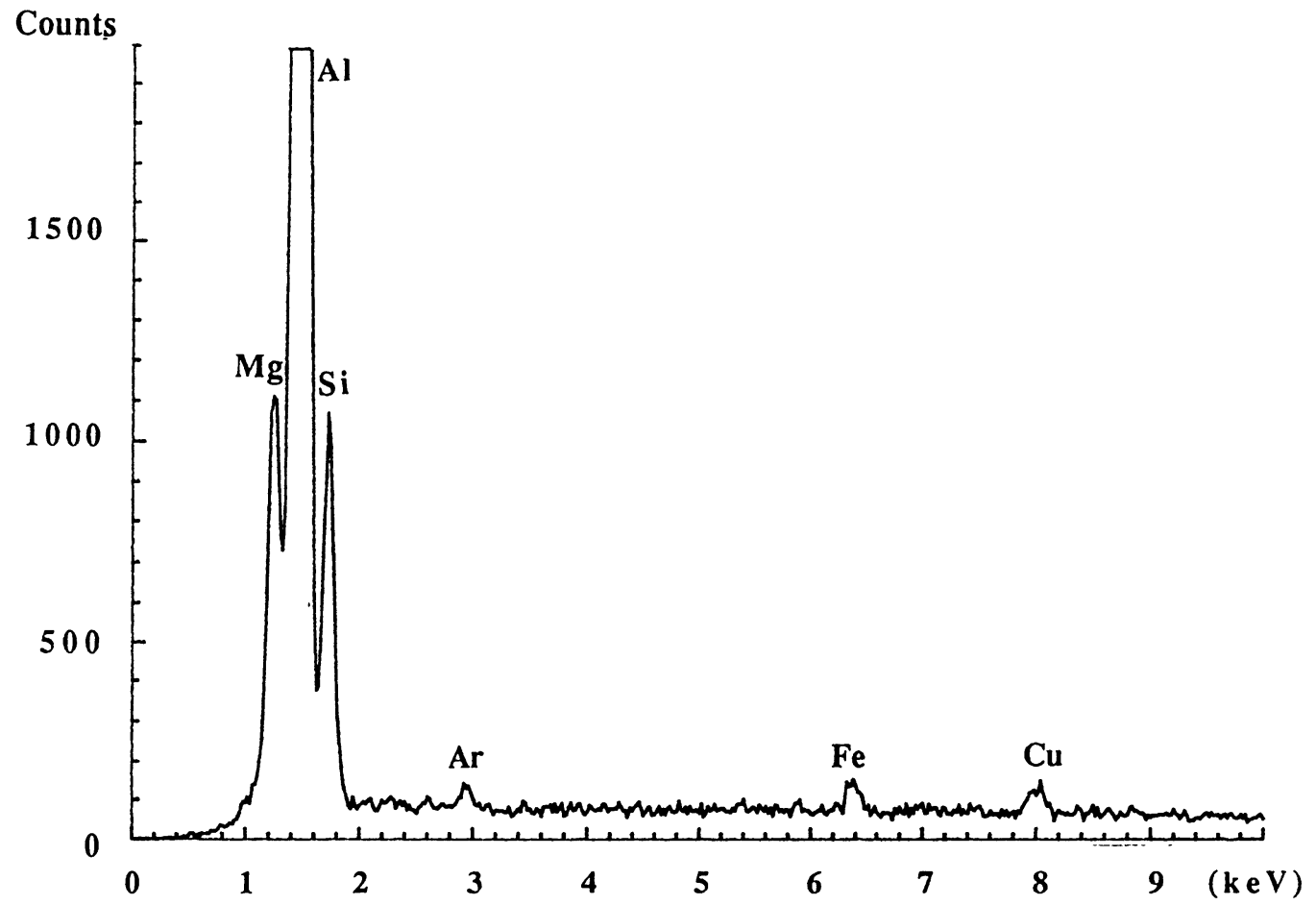

\section{Counts}

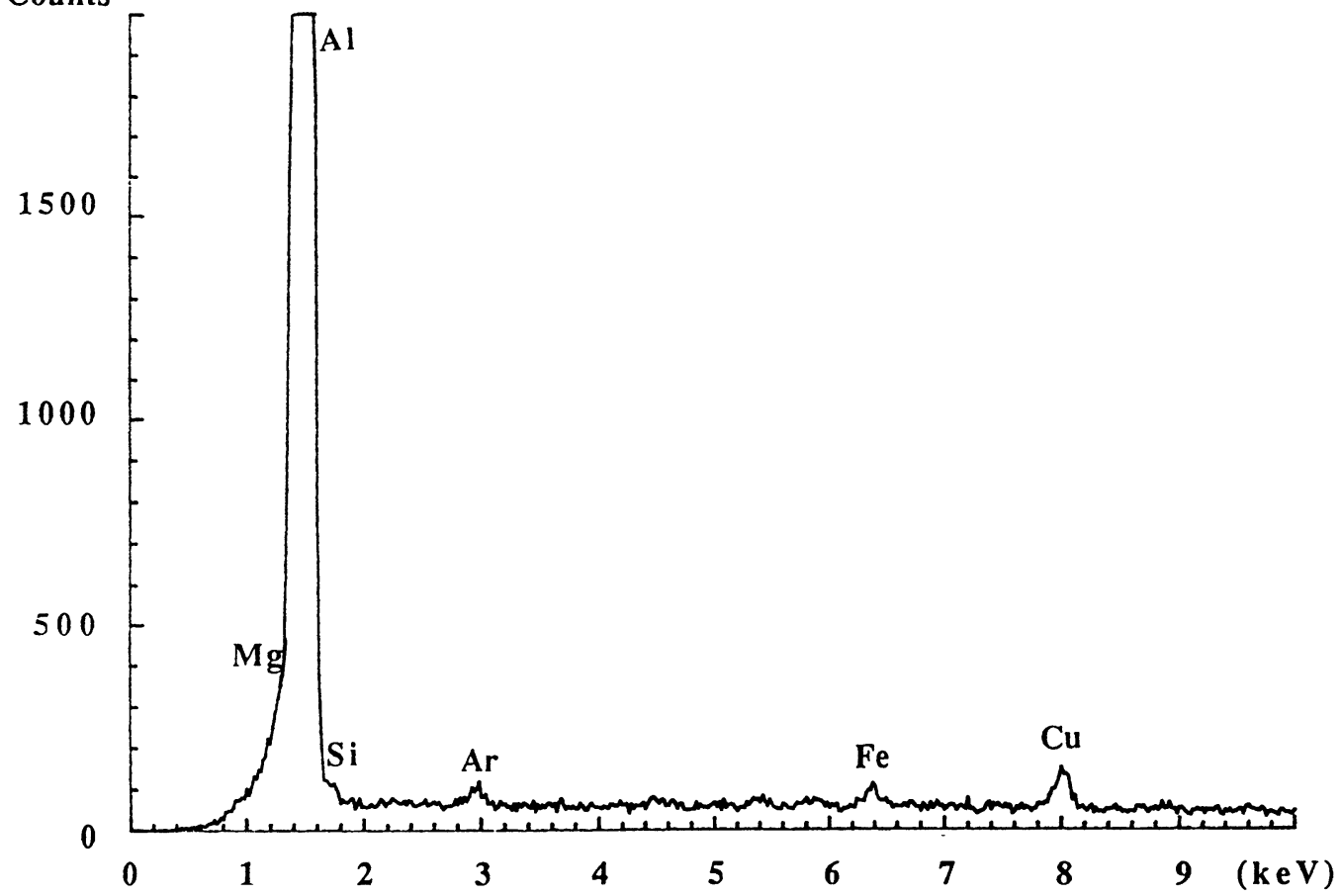

Fig. 8. $-\delta$ alumina fibres / 6061 composite after T6 treatment. a) STEM X-ray analyses in the fibre (a-1) and in the matrix (a-2) (probe size $5 \mathrm{~nm}$ ). b) microscope linescan through a fibre. 


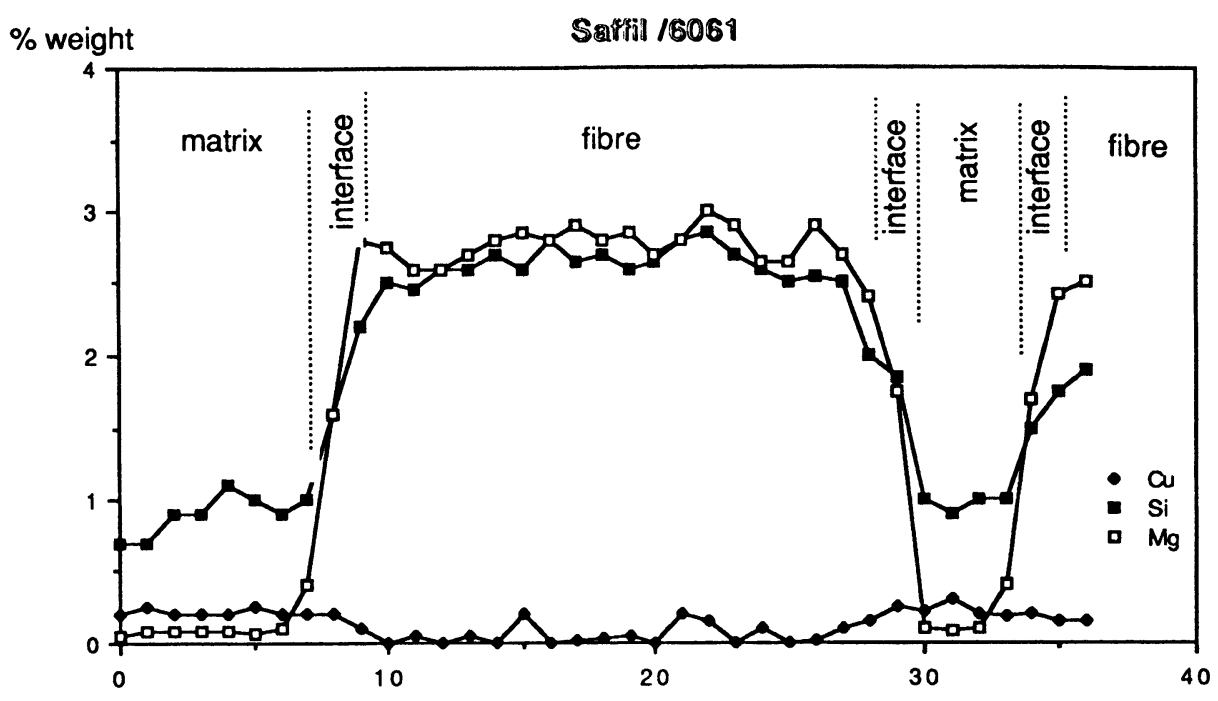

Fig. 8b.

As a consequence, a sufficient time of high temperature treatment is essential to dissolve them, but possible interfacial reactions can also be enhanced during this heat treatment. Such a disadvantage would be reduced in cleaner alloys. Indeed the presence of special additional elements which are grain-growth-inhibiting elements in conventional alloys are not required. Nevertheless, alloying elements which are responsible of structural hardening must be conserved. As presented in figure 1, the grain size in the matrix is controlled by the reinforcement itself and not by dispersoid particles. On this subject, the increase of yield stress in DMMCs is partially understood by the reduced grain size in the matrix according to the Hall-Petch law.

All the observations at the fibre-matrix interfaces for all the studied composites, except the SiC whiskers / 2024 alloy elaborated by powder metallurgy, exhibit an important interaction between the magnesium, initially alloying element (1.5\% for 2024 alloy and $1 \%$ for 6061 alloy) and the various types of fibres.

For all the materials elaborated by squeeze casting, the interaction between the magnesium and the fibres is initiated during the processing when the aluminium alloy is still liquid. Magnesium diffuses from the matrix to the fibres where the solidification ends. As a consequence, a reaction occurs between the magnesium trapped near the fibres and the fibres constituents, especially the silica present in the fibre or laying at its periphery $[4,21]$.

For the material $\delta$ alumina / 6061 alloy, a reaction occurs between the magnesium and the amorphous silica present in the fibre. The emphasized degradation of the fibre during the long time aging at $808 \mathrm{~K}$, allows to understand the mechanism of the reaction. In table III, we observe that:

- silicon has left the fibre. It is concentrated in complex particles. No significant increase of silicon in the matrix is observed.

- magnesium is distributed in the whole fibre. The matrix regions nearest to the fibre are depleted of magnesium.

This degradation sequence is governed by the reaction between magnesium and alumina or 

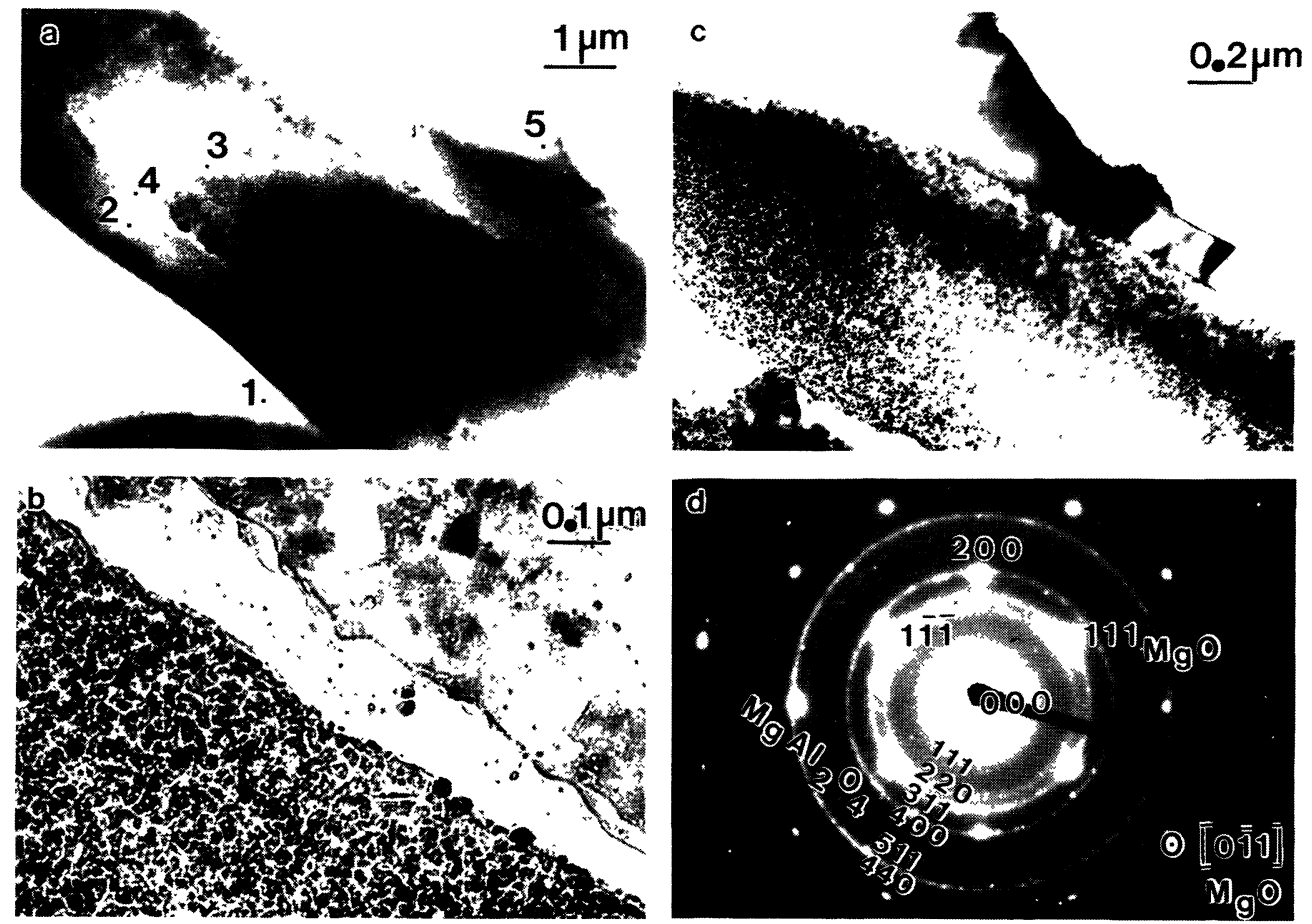

Fig. 9. - a) Longitudinal view of a $\delta$ alumina fibre after heat treatment at $808 \mathrm{~K}$ during 120 hours. b) enlargement of region 4. c) enlargement of region 5. d) diffraction pattern of the selected area centered on region 4. Numbers indicate the analysed points by EDS (results are reported in table III). 1: matrix, 2 and 3: original small grain regions, 4: original single crystal region, 5: particle attached to the external part of the fibre.

silica [24] according to the reactions:

$$
\begin{gathered}
\left\langle\mathrm{SiO}_{2}\right\rangle+2 \mathrm{Mg} \rightarrow\langle 2 \mathrm{MgO}\rangle+\mathrm{Si} \\
2\left\langle\mathrm{SiO}_{2}\right\rangle+2 \mathrm{Al}+\mathrm{Mg} \rightarrow\left\langle\mathrm{MgAl}_{2} \mathrm{O}_{4}\right\rangle+2 \mathrm{Si} \\
\left\langle\mathrm{Al}_{2} \mathrm{O}_{3}\right\rangle+3 \mathrm{Mg} \rightarrow 3 \mathrm{MgO}+2 \mathrm{Al}
\end{gathered}
$$

The $\mathrm{MgAl}_{2} \mathrm{O}_{4}$ spinel observed in figure 9 seems to be a consequence of the reaction (2). Indeed this reaction is energetically more favorable [24] for low content mangesium alloys, which is our case (1.5wt\% Mg in 2024 alloy and $1 \mathrm{wt} \% \mathrm{Mg}$ in 6061 alloy) [22, 23].

The presence of magnesium oxide instead of monocrystalline alumina is due to a direct reduction of alumina according to the reaction (3). This reaction provides some native aluminium which diffuses in the other parts of the fibre where it may contribute to the reaction (2).

In some $\delta$ alumina fibres, just after T6 treatment, we observed that the magnesium has diffused inside the whole fibre (Fig. 8), even to the core.

Such a reaction can be surprising since by considering previous results [20]. It can be attributed to problems occuring during processing, probably preform overheating or to too long exposures to the liquid phase.

For the mullite / 6061 alloy, the reaction seems to take place between the magnesium and the external zone of the fibres. The main interfacial reactions is the mullite reduction by magnesium 

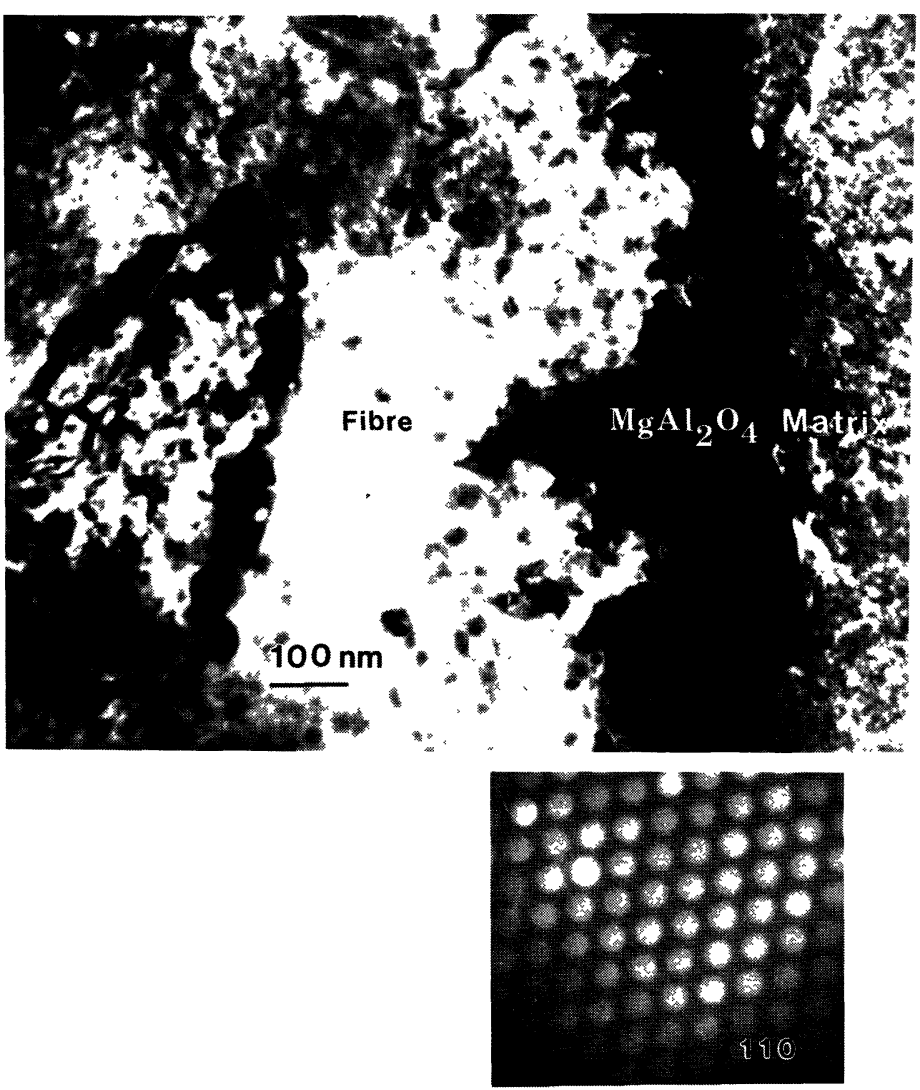

a)

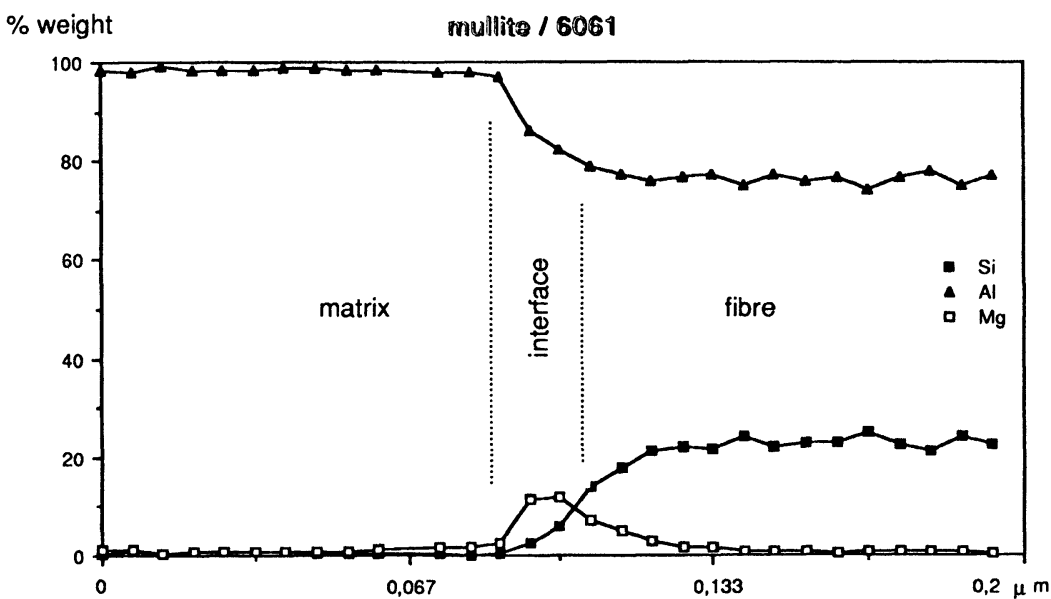

b)

Fig. 10. - Mullite / 6061 composite after 50 hours at $808 \mathrm{~K}$. a) $\mathrm{MgAl}_{2} \mathrm{O}_{4}$ localization at the interface. b) STEM elemental concentration linescan through the interface. c) Elemental X-ray mapping of $\mathrm{Mg}, \mathrm{Al}$ and $\mathrm{Si}$. For each image the element localization corresponds to the clearer part. d) EELS analyses: the measurements of the areas $S_{x}$ between the background fitting curves (...) and the experimental distributions ( - ) in a $150 \mathrm{eV}$ wide window after the edges allow to obtain the atomic ratio: $\mathrm{Mg} / \mathrm{O}=0.25$ and $\mathrm{Al} / \mathrm{O}=0.57$ by using the classical quantitative analysis formula $\mathrm{C}_{x} / \mathrm{C}_{\mathrm{O}}=\mathrm{S}_{x} / \mathrm{S}_{\mathrm{O}} \cdot \sigma_{\mathrm{O}} / \sigma_{x}$ where $\sigma$ are the excitation partial cross sections for the $1 \mathrm{~s}$ electrons. The values in a $150 \mathrm{eV}$ energy loss range and a $9 \mathrm{mrd}$ collection angle, for $\mathrm{Al}$, $\mathrm{Mg}$ and $\mathrm{O}$ respectively are 79,140 and $1680 \times 10^{-24} \mathrm{~cm}^{2}$. 

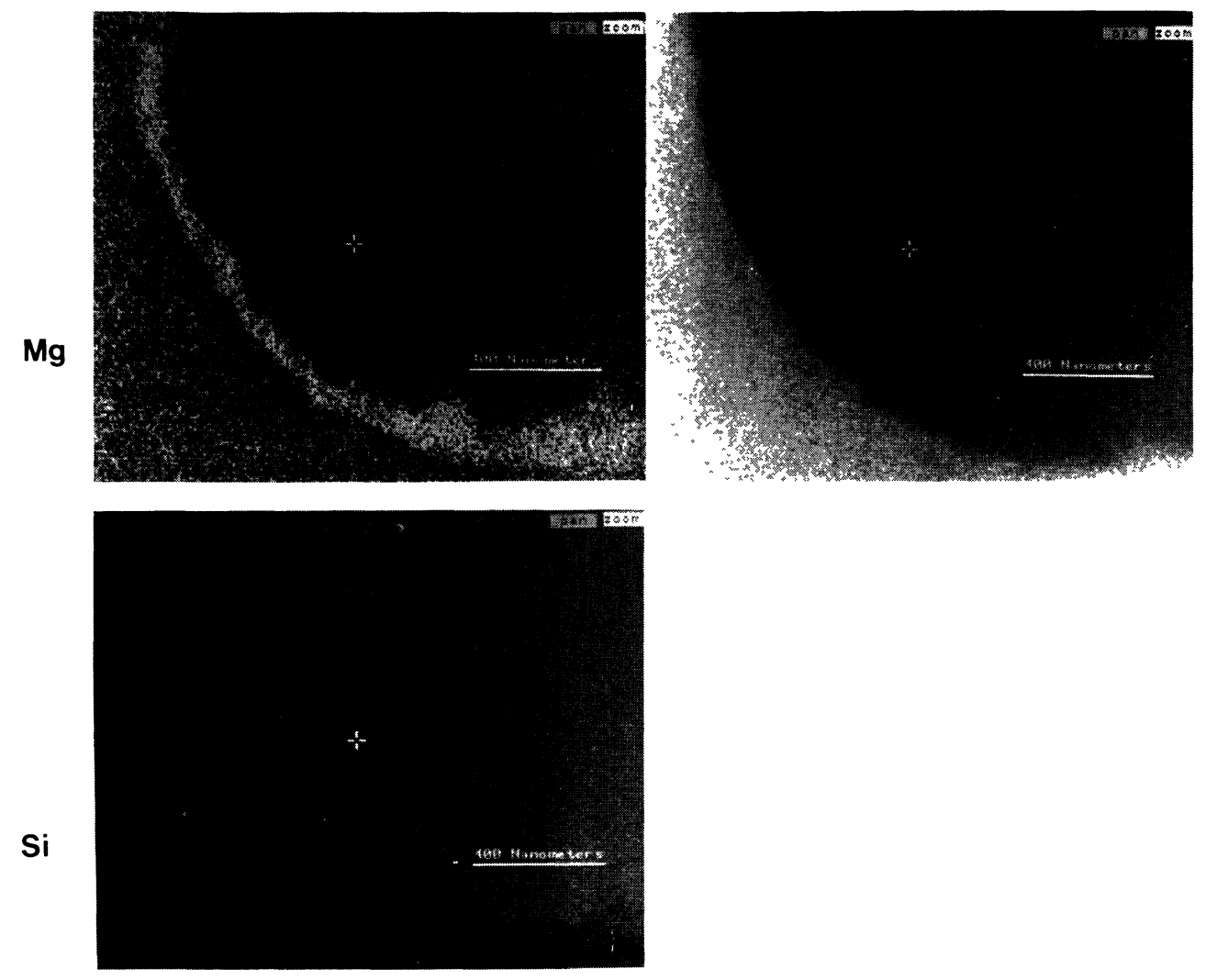

C)

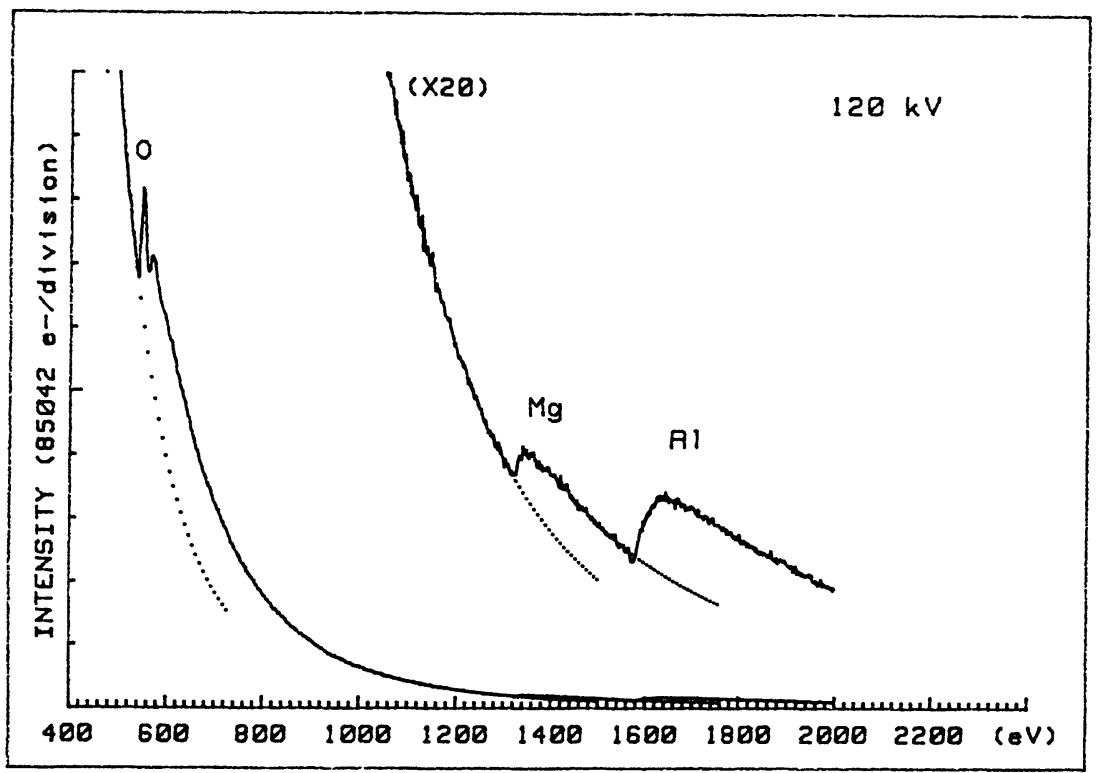

Fig. 10.

d) 
through reaction between $\mathrm{Si}, \mathrm{O}, \mathrm{Mg}$ and $\mathrm{Al}$ leading to $\mathrm{MgAl}_{2} \mathrm{O}_{4}$ spinel formation. This reaction involves an uneasy decomposition of the mullite, so the magnesium reactivity appears less important with these fibres than with $\delta$ alumina fibres.

For the SiC whiskers / 2024 alloy elaborated by squeeze casting, we get a clear evidence of magnesium enrichment at the interface. The previous results lead to the conclusion that a similar reaction process takes place if we assume that a silica layer is present at the whisker periphery.

Depending on the preform temperature, an oxidation of the fibres occurs according to the reaction:

$$
\langle\mathrm{SiC}\rangle+3 / 2 \mathrm{O}_{2} \rightarrow\left\langle\mathrm{SiO}_{2}\right\rangle+\mathrm{CO}
$$

which has been confirmed by Auger analysis [25].

In conclusion, the various analytical technics (EDS, EELS, CBD) allowed us to identify $\mathrm{MgAl}_{2} \mathrm{O}_{4}$ at the interface after a long annealing treatment. Magnesium seems to diffuse during processing from the matrix to the fibres where it is trapped and reacts with fibre surface. During annealing treatment, this reaction proceeds inside the fibres.

The longer heat treatments only have allowed to identify $\mathrm{MgAl}_{2} \mathrm{O}_{4}$ at the interface. This is important since the formation of brittle phases at the fibre-matrix interface are disastrous for he mechanical behaviour of the material. Also, the spinel formation withdraws the magnesium from: the matrix, leading to an insufficient magnesium concentration in the alloy to allow $\mathrm{Mg}_{2} \mathrm{Si}$ precipitation. That makes the composite not suitable for structural hardening. This demonstrates that matrix compositions have to be tailored to the nature of the reinforcement and to the processing route.

\section{Acknowledgements.}

This work has been partly supported by the MRT financial support (GIS Composites à Matrices Métalliques). The authors thank the Pechiney Group for supplying the different samples.

\section{References}

[1] OHORI K., WatanABE H., TAKEUChI Y., Mater Sci. Technol. 3 (1987) 57.

[2] McKimpson M. G., SCOTT T. E., Mater. Sci. Eng. A107 (1989) 93.

[3] Mortensen A., CORnie J. A., Flemings M. C., J. Metals 2 (1988) 12.

[4] Suganuma K., OKamoto T., Hayami T., OKu Y., SuZUki N., J. Mater. Sci. 23 (1988) 1317.

[5] Madeleno U., LiU H., Shinoda T., Mishima Y. SuZUKI T., J. Mater. Sci. 25 (1990) 3273.

[6] Lloyd D. J., Lagace H., McLeOD A., MORRIS P. L.,Mater Sci. Eng. A107 (1989) 73.

[7] Viala J. C., ForTiER P., BOUIX J., J. Mater. Sci. 25 (1990) 1842.

[8] Peteves S. D., Tambuyser P., Helbach P., Audier M., Laurent V., Chatain D., J. Mater. Sci. 25 (1990) 3765.

[9] FrIEND C. M., HoRSFall I., LuXTON S. D., Young R. J., Cast reinforced Metal Composites. ASM S-G. Fishman and A. K. Dhingra Eds. ASM (1988) p. 309.

[10] RaCK H. J., Sixth Int. Conf. on Comp. Mat., F. L. Mattews et al. Ed. (Elsevier, 1987) p. 2382.

[11] ChristMAN T., SURESH S., Acta Metall. 36 (1988) 1691.

[12] Dafir D., Cardinal S., Borrelly R., Gobin P. F., Merle P., Proc. J. Nat. Compos. 7-AMAC (1990).

[13] ABIS S., DONZELli G., J. Mater. Sci. Let. 7 (1988) 51.

[14] ZaNChi G., PereZ J. P., SEvely J., Optik 43 (1975) 495.

[15] NUTT S., J. Amer. Cer. Soc. 71 (1988) 149.

[16] CAMERON W. E., Amer. Mineral. 62 (1977) 747. 
[17] Kriven W. M., Pask J. A., J. Amer. Cer. Soc. 66 (1983) 649.

[18] RIBES H., Thesis INP Grenoble (1989).

[19] STEPHENSON T., LE PETITCORPS Y., QUENISSET J. M., E-MRS Strasbourg (1990).

[20] MOLINS R., BARTOUT J. D., BIENVENU Y., E-MRS. Strasbourg (1990).

[21] LegouX J. G., Salvo L., Ribes H., L'Esperance G., Suery M., The Minerals, Metals and Materials Society (1989) 187.

[22] Munitz A., METZGER M, MEHrabain R., Met. Trans. 10A (1979) 1491.

[23] KARLSEN D. O., BorRadaile J. B., GJonnes J., TAFTo J., International Symposium on Metallurgy and Materials Science, RISO, (1988) 421.

[24] Levi C. G., AbBaschian G. J., Mehrabian R., Met. Trans. 9A (1978) 697.

[25] BOUVAIST J., TORRE J. P., Compte rendu de fin d'étude. contrat MRES n ${ }^{\circ}$ 55-S.O.929 (1987).

[26] EGERTON R. F., Electron Energy Loss Spectroscopy in the Electron Microscope (Plenum Press. New York, (1986). 